\title{
Extreme geomorphic events in the contemporary evolution of forested slopes in a Central European mountain range, the Sudetes
}

\author{
Piotr Migońn \\ ${ }^{1}$ Institute of Geography and Regional Development, University of Wrocław, Poland \\ Received 3 December 2017; Revised 10 December 2017; Accepted 12 December 2017 \\ *Correspondence to: Piotr MIGOŃ; e-mail: piotr.migon@uwr.edu.pl
}

\begin{abstract}
Forested slopes of the Sudetes have long been implicitly considered as stable under contemporary environmental conditions, with little geomorphic change throughout the Holocene. This view is difficult to sustain and this review-type paper brings together evidence that infrequent but potent surface processes locally cause significant remodelling of slopes and regolith removal or redistribution. These processes are debris flows, shallow and deepseated landslides, episodes of efficient linear water erosion and windthrows. All are triggered by exceptional meteorological events such as heavy rain or strong wind, but additional factors of slope steepness and suitable lithology play a role. Scarce database does not permit to firmly establish recurrence intervals of such events but they seem to occur at least once per decade (within the entire mountain range) for rain-induced phenomena and two-three times per century for wind-induced phenomena.
\end{abstract}

\section{KEYWORDS}

Geomorphic system; hillslope geomorphology; debris flows; landslides; windthrow

\section{Introduction}

Most mountainous terrains in Central Europe (i.e. those in Germany, Czechia, Poland, Slovakia, Hungary) reach only moderate altitudes of 800-1500 m a.s.l. and hence, do not rise above the timberline. Thus, their hillslopes remain forested, unless land cover has changed due to human use, and likely remained so throughout the Holocene. The continuous forest cover implies less geomorphic activity than on bare slopes present above the timberline where both physical weathering is more efficient and sparse vegetation does not act as a significant obstacle to superficial 
mass movements (Kotarba and Starkel, 1972). An additional factor controlling surface dynamics is bedrock lithology and structure. Whereas in flysch settings, e.g. in the Outer Carpathians, landslides are common and capable of large-scale hillslope remodelling (e.g. Rączkowska et al., 2012; Pánek et al., 2013), in basement rocks typifying mountainous terrains of the Bohemian Massif and the Mittelgebirge belt further west in Germany such high-magnitude slope processes are infrequent. Here, the general view is one of implied overall geomorphic stability of forested hillslopes, slow and continuous pedogenesis, and considerable periglacial inheritance recorded in landforms and cover deposits (e.g. Jahn, 1989; Kleber and Terhorst, 2013). Nevertheless, extreme geomorphic events within the slope denudational systems do occur in these basement-dominated terrains too, although their significance in the long-term landscape evolution is uncertain. 'Extreme' in this context means events both rare and capable of producing significant, even if local, geomorphic effect in short time (minutes, hours, days).

The purpose of this paper is to look at these apparently infrequent extreme events affecting the forested hillslopes in a broader perspective. The area discussed is the mountain range of the Sudetes - the highest terrain within the Bohemian Massif that straddles the Czech/Polish boundary along the length of c. $300 \mathrm{~km}$ (Fig. 1). Although the most elevated parts of the Sudetes rise above the timberline, such areas have very limited extent ( 57 $\mathrm{km}^{2}$ in total, after Treml and Banaš, 2003) and the majority of hillslopes are forested. However, the long-term human impact and intense forest exploitation, whose onset dates back to the late medieval times $\left(12-14^{\text {th }}\right.$ century) (Valde-Nowak, 1999) and which continues nowadays, resulted in significant alterations of forest stands. Therefore, the forest belt of the Sudetes cannot be considered a natural environment, except for a few isolated small areas.

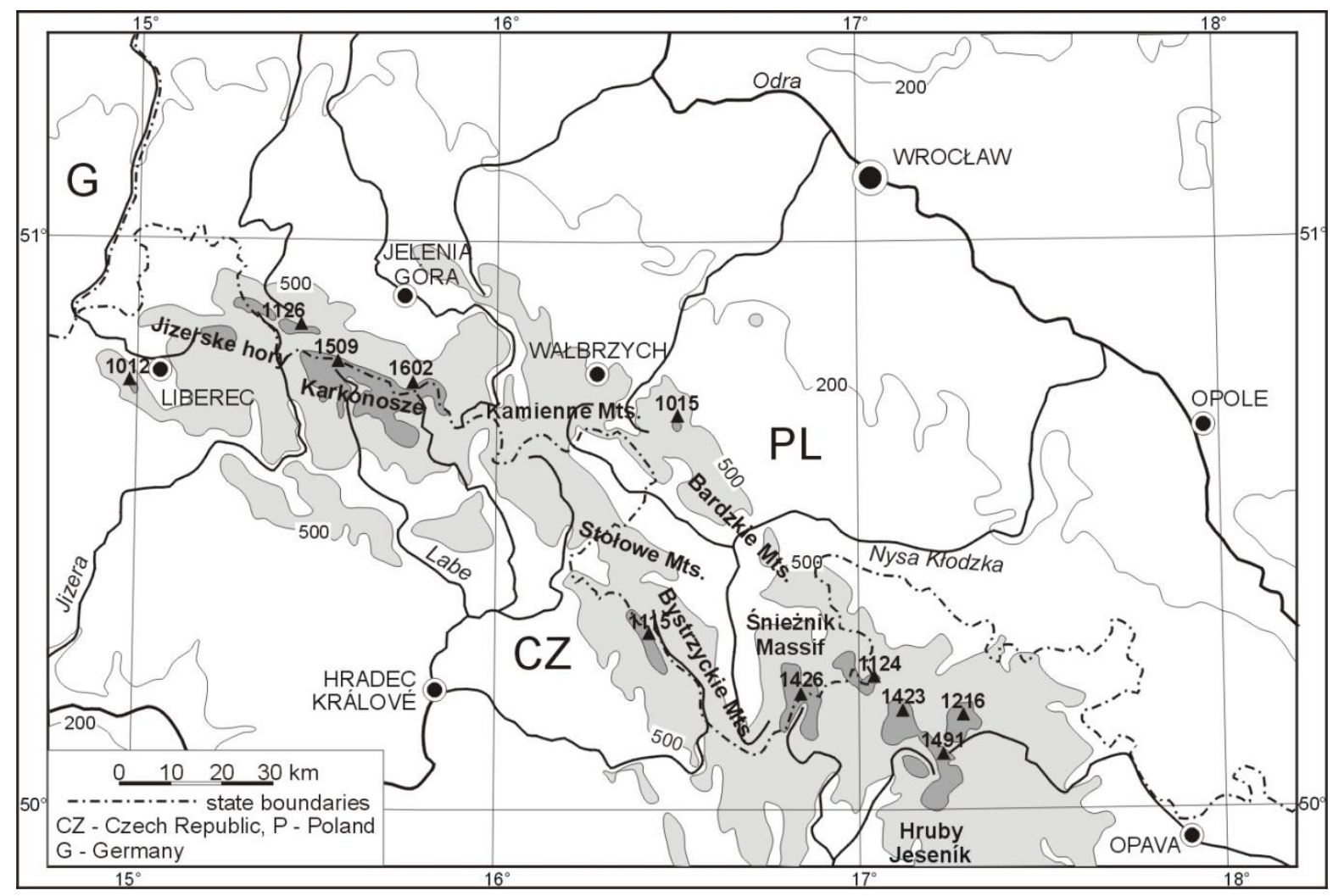

Figure 1 The study area of the Sudetes 
The structure of the paper, which is mostly of review type, is bipartite. First, various types of extreme geomorphic events and their geomorphic impacts will be presented. The focus is on hillslope processes (mass movements, erosion, windthrow), leaving aside floods, extensively treated elsewhere (e.g. Kasprzak and Migoń, 2015). Second, their spatial and temporal context will be discussed, followed by considerations of their significance for the contemporary and Holocene geomorphic system of the Sudetes. This paper provides also an opportunity to revisit and update information about extreme geomorphic events presented by Migoń et al. (2002).

\section{Study area}

\subsection{Altitudes and landforms}

The Sudetes are perhaps the most representative among the Central European mountains and uplands outside the Alpine/Carpathian belt. Along with their neighbours, they are an old Variscan orogen, hence the predominance of pre-Permian igneous (granites) and metamorphic rocks (gneisses, schists), which was rejuvenated in the late Cenozoic in response to the crustal stresses exerted by the rising Alps and the Carpathians. However, PermoCarboniferous and Mesozoic sedimentary cover rocks occur too, especially in vast intramontane depressions. Differential uplift and subsidence have produced the complicated topography of the present-day Sudetes, with secondary uplifted blocks, moderately elevated uplands and intramontane basins (Migoń, 2011). The highest terrains in the Sudetes exceed $1400 \mathrm{~m}$ a.s.l. (Karkonosze - 1602 m, Hruby Jeseník - 1492 m, Śnieżnik Massif - $1425 \mathrm{~m}$ ), although the most common altitude of watershed ridges is $800-1000$ $\mathrm{m}$ a.s.l. The floors of intramontane basins, in turn, lie at $300-500 \mathrm{~m}$ a.s.l., creating altitude contrasts reaching locally $1000 \mathrm{~m}$. The average altitude of the timberline is $1230 \mathrm{~m}$ a.s.l. in the Karkonosze (West Sudetes) and $1310 \mathrm{~m}$ a.s.l. in the Hrubý Jeseník range (East Sudetes) (Treml and Banaš, 2003), whereas the upper limit of deforestation for agriculture reached 800-900 m a.s.I. (Latocha, 2007,
2009). However, the extent of deforestation was clearly slope-dependent and steep slopes with stony soils were left forested even in the foothills belt, below $400 \mathrm{~m}$ a.s.l.

It is very difficult to generalize about morphology and landforms for the region of such complicated topography and geology. Nonetheless, major landforms within the forest belt are (Fig. 2): (a) low-relief water divide surfaces, regarded as remnants of pre-Neogene planation surfaces, but some are clearly structure-controlled, following the sub-horizontal dip of strata; (b) deeply incised fluvial valleys, with valley sides locally as steep as $30-40^{\circ}$; (c) moderately inclined $\left(10-20^{\circ}\right)$ slopes, connecting (a) and (b); (d) isolated steep-sided elevations on more resistant bedrock variants, most commonly volcanic, with slope inclinations locally above $50^{\circ}$.

\subsection{Climate and extreme weather events}

The contemporary climatic conditions of the Sudetes reflect regional circulation patterns within Central Europe (Sobik, 2005). Advections of humid polar maritime air masses from the west are most common and occur during c. $65 \%$ of the year on average, $14 \%$ among them being the cases of fairly quick movement over western Europe that takes less than 24 hours to reach the Sudetes. They are associated with cyclonic circulation and may bring considerable rainfall along the cold front. Strong wind may accompany the westerly circulation, taking the form of a foehn wind across major topographic barriers. Bora winds are characteristic too, being channelized by chains of intramontane troughs and basins. In turn, polar continental air masses arriving from the east account for c. $31 \%$ days of the year on average.

Mean annual temperatures reach $7^{\circ} \mathrm{C}$ in the foothills and intramontane basins, dropping to $0^{\circ} \mathrm{C}$ on the highest peaks, consistent with the general altitude-temperature relationship. However, the effects of altitude are modified by the foehn effect and leeward sites typically have higher mean annual temperatures than dictated by the altitude alone. The mean summer temperatures reach $16^{\circ} \mathrm{C}$ in the foothills and $12-13^{\circ} \mathrm{C}$ at $800-900 \mathrm{~m}$ a.s.l., whereas the respective values for winter are $-2^{\circ} \mathrm{C}$ and $-5^{\circ} \mathrm{C}$. 


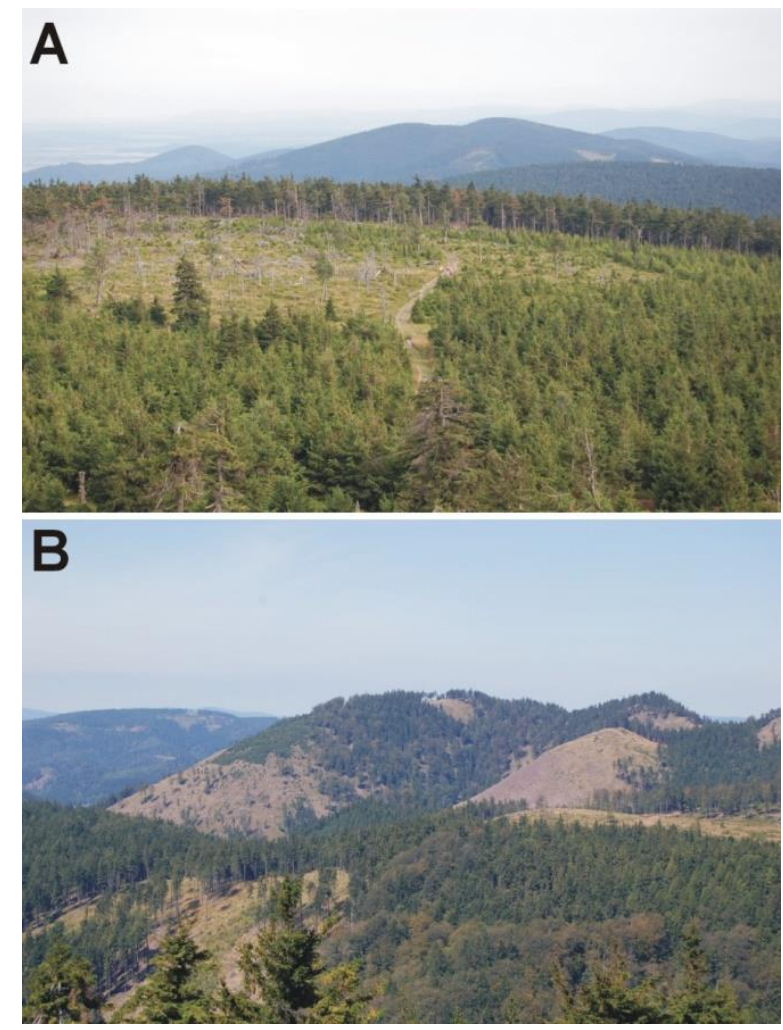

Figure 2 Two representative scenes from the forest belt of the Sudetes: (A) low-relief, subdued water divide surfaces (Sowie Mts.), (B) moderately steep slopes within fluvial valley

Likewise, annual precipitation reflects the combined effects of altitude and relief. It reaches $700-800 \mathrm{~mm}$ in the foothills and $1200-1500 \mathrm{~mm}$ on elevated planation surfaces, with the westernmost parts of the Sudetes being much rainier than the eastern parts. The role of rain shadow is significant, accounting for less rainfall on leeward slopes and basins. Snow cover remains from 50 days per year in the foothills to 200 days in the parts of the West Sudetes directly exposed to the advection of humid air masses from the west.

Although the climate is generally considered as temperate and mild, extreme atmospheric events occasionally occur (Sobik and Błaś, 2010). From the geomorphological perspective, two types of events are of prime importance: heavy precipitation and strong wind. The former is associated with two situations. First, longer periods of intense rain are generated by macroscale convergence in cyclonic circulation patterns. They may last from one to five days and extend over considerable area. For example, extremely high rainfall in early July 1997, exceeding $500 \mathrm{~mm}$ in five days, affected nearly half of the Sudetes, along with the adjacent part of the Carpathians (Czerwiński and Żurawek, 1999). Second, localized convection and the development of Cumulonimbus clouds leads to brief (even less than 1 hour), but very efficient episodes of very heavy rain (cloudbursts). The most extreme examples recorded were $176 \mathrm{~mm} / 75$ minutes (year 1914), $183 \mathrm{~mm} / 90$ minutes (1968) and $193 \mathrm{~mm} / 2$ hours (1951), but intensities in the range of 50 $\mathrm{mm}$ /hour are more common (Sobik and Błaś, 2010).

Similarly to precipitation, strong winds may be divided into two groups (Sobik and Błaś, 2010). First, the Sudetes are occasionally affected by large-scale cyclonic events, when atmospheric pressure in the centre drops below $970 \mathrm{hPa}$ and the wind speed exceeds $100 \mathrm{~km}^{*} \mathrm{~h}^{-1}$. A recent example is provided by the Kyrill storm on 18-19 January 2007 which brought significant damage, particularly to the forest stands (Pawlik, 2012). Second, some foehn winds may be associated with wind speed above 60 $\mathrm{km}^{*} \mathrm{~h}^{-1}$ and their devastating effects are exacerbated by the tunnelling effect of deeply incised valleys (Kwiatkowski, 1969)

Not much of solid knowledge about the climatic conditions during an earlier, pre-observation period can be provided. Likewise, the climatic record of the Holocene is poorly documented and insufficiently constrained. Therefore, it seems more appropriate to address these issues in the subsequent discussion, in section 4 .

\section{Extreme events - processes and landforms}

\subsection{Debris slides and flows}

Debris flows are a typical component of a highmountain denudational system such as the Tatra Mountains in the Carpathians (Kotarba et al., 1987, 2013). However, they may occur in medium-altitude mountains such as the Sudetes too and indeed, this mountain range stands out among the other Mittelgebirge ranges in terms of frequency and dimensions of debris flows. Debris flows are known 
from the glacial cirques of the Karkonosze, but in the context of this paper debris flow occurrences in the forest belt are of particular significance. Furthermore, two situations need to be distinguished: (a) flows generated above the timberline which reach the forest belt and become dissipated within it; (b) flows whose source areas are within the forest.

Debris flows of the first type are common in the Karkonosze, especially in the deep, glaciallyremodelled valleys in the eastern part (Pilous, 1977; Migoń and Parzóch, 2008). They are generated above the timberline, in joint-controlled ravines or within convex slopes with thin regolith cover, and continue movement after reaching the forest boundary (Fig. 3). The length of tracks within the forest is from $100 \mathrm{~m}$ to as much as $300 \mathrm{~m}$, i.e. two thirds of the total length. Flows of the second type commence as shallow slides of the regolith cover, usually very thin (c. $1 \mathrm{~m}$ thick), within forested slopes of considerable steepness $\left(>25^{\circ}\right)$. They have been recorded in the Karkonosze, Jizerské hory, Śnieżnik Massif and, particularly, Hruby Jeseník range (Hrádek, 1984; Pilous, 2011; Parzóch et al., 2012; Roštínský et al., 2013). Some transform into flows and move along a narrow track (in respect to length), whereas others continue sliding down to the valley floor across a wider zone up to $30 \mathrm{~m}$ such as the debris slide in the Śnieżnik Massif in 2011 (Parzóch et al., 2012). The length of flow tracks/slide-affected zones varies from a few tens of metres to $1 \mathrm{~km}$ (Pilous, 2011), depending on the available slope length.

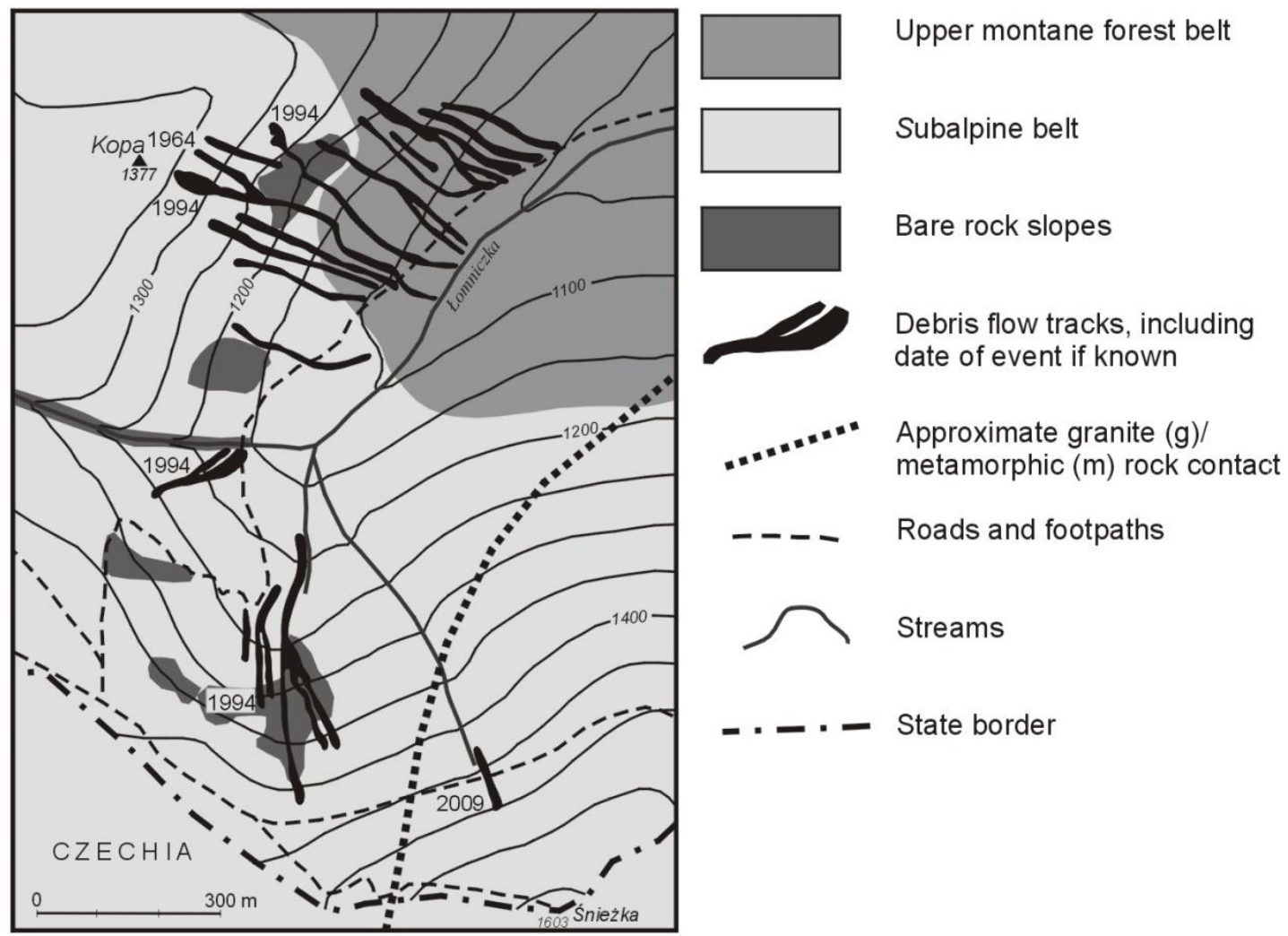

Figure 3 The distribution of debris flow tracks in the Łomniczka Valley, Karkonosze Mts. (after Parzóch and Migoń, 2010)

Typical landforms indicating debris flow tracks are central troughs and lateral levees, the latter up to $2 \mathrm{~m}$ high (Fig. 4). Troughs may still host remnant regolith but complete erosion down to bedrock may occur too. If this is the case, the longitudinal profile of a track is irregular, with rocky sections alternating with the regolith-covered ones. Boulders as big as 3 $\mathrm{m}$ high were observed within the levees. Distal deposition may occur in the form of a distinct toe, but along other flow tracks one can observe gradual 
disappearance of characteristic landforms or the flow reached the channel and continued as hyperconcentrated flow (e.g. 1921 event in Hruby Jeseník or 2010 event in the Jizerské hory).

\subsection{Deep-seated landslides}

Deep-seated landslides, in contrast to shallow debris slides requiring thin regolith and steep slope, are much more geology-dependent. The predominant basement rocks of the Sudetes, only superficially weathered, do not provide a setting conducive to deeply rooted slide displacements. However, in special geological circumstances such as the occurrence of tough, heavy but jointed volcanic rocks over weaker, deformable sedimentary formations landslides do form. The best researched area in this respect is the range of Kamienne Mountains in the Central Sudetes, where around 50, apparently relict landslides have been identified under forest, with the most extensive ones covering $>10$ ha, some joining into landslide complexes up to 40 ha (Migoń et al., 2010, 2014, 2017). Further, but fewer examples were reported from the adjacent Wałbrzyskie Mountains, the tableland of the Stołowe Mountains (Duszyński et al., 2017), Kaczawskie Mountains (Kowalski, 2017), Bystrzyckie Mountains (Różycka et al., 2017) and Bardzkie Mountains (Jancewicz and Traczyk 2017), including a large historic (1598) translational slide in the Nysa Kłodzka gorge which dammed the river (Oberc, 1957; Parzóch and Migoń, 2010).

Morphology and morphometry of landslides suggest that they represent different genetic types (Migoń et al., 2017; Różycka et al., 2017). Some show geomorphic signatures of rotational slides, with arcuate rocky or debris-covered head scarps, back-tilted benches, locally multiple, closed hollows and convex toes. Others lack back-tilted blocks and seem to result from translational wedge-type failures. In turn, elongated hummocky landslide bodies confined to valleys, with scattered boulders of different size, indicate complex movement involving slide and flow. Exposure of head scarps in jointed bedrock initiated further gravity-driven movements of individual rock fragments and the development of angular scree (Fig. 5).
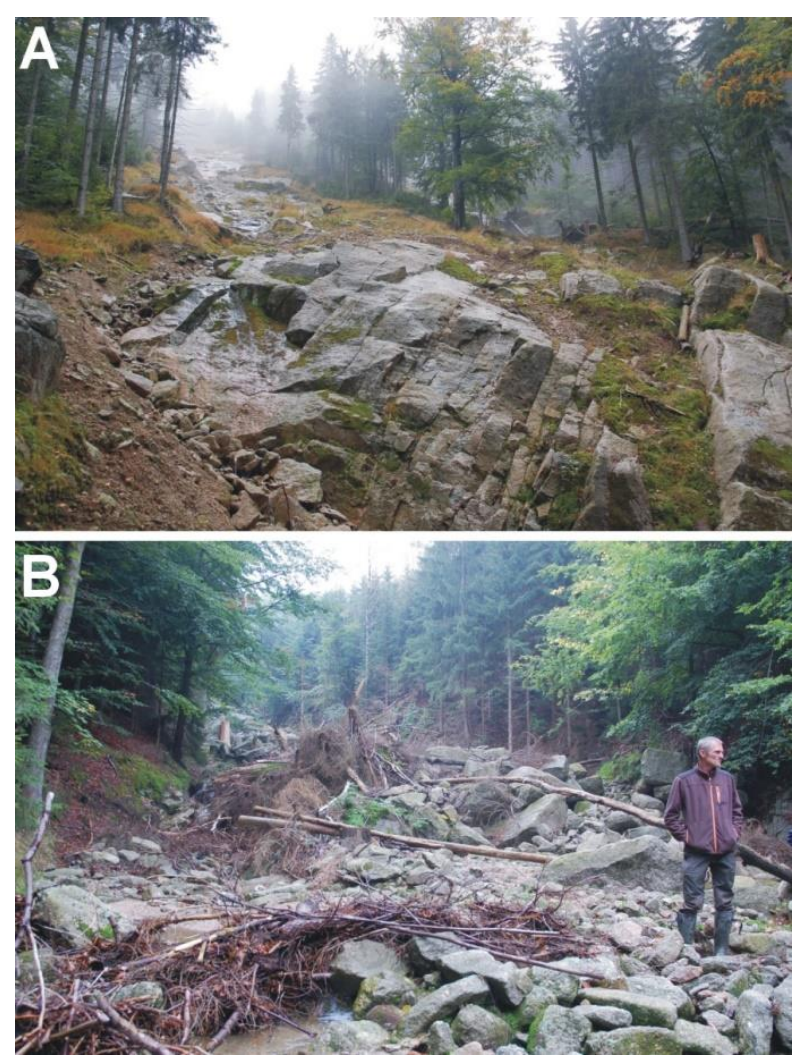

Figure 4 Geomorphic and ecological consequences of a recent (2010) debris flow in the Jizerské hory (Czechia). (A) The complete removal of hillslope regolith and exposure of bedrock along the track, (B) Boulder and woody debris accumulation in the distal part

The age of the majority of landslides is not known and only a few can be safely linked with historical events such as the 1598 landslide in Bardo (Oberc, 1957). A rare example of a recently (2016) developed slide in Wleń was described by Kowalski (2017). Otherwise, even the episodes of heavy rainfall (1997, 1998, 2006 and 2010) triggered only shallow regolith-confined slides within valley sides (Aichler and Pecina, 1998; Żurawek 1999), but no deep-seated bedrock-rooted landslides were activated. However, there are indirect indicators that at least some landslides originated or were reactivated during the Holocene. These include differences in soil characteristics (Kacprzak et al., 2013), sparse radiocarbon dates from closed depressions within two landslides in the Kamienne Mountains (Synowiec, 2005), dendrochronological signals of considerable stress exerted on trees 
growing on landslides (Malik et al., 2016), various signals of activity of scree slopes below head scarps (Remisz, 2012; Remisz and Bijak, 2012) and evident differences in the clarity of geomorphic features of landslides, suggesting a variety of ages.

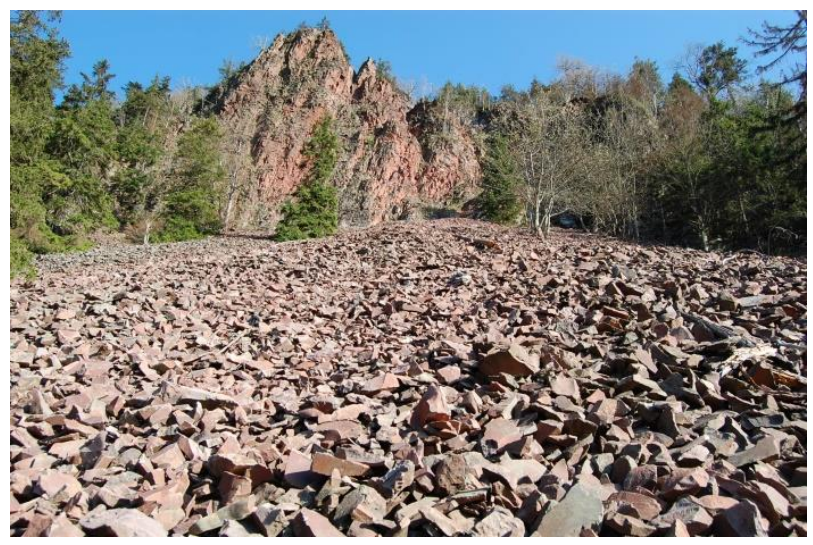

Figure $\mathbf{5}$ Contemporary activity of a scree slope at the foot of a landslide head scarp, Mt. Suchawa, Kamienne Mts.

The geomorphological diversity of landslides suggests also that displacements may have occurred with different rates. Certainly, as the historical records from Bardo inform, some may have been produced almost instantaneously and were 'extreme events' sensu stricto. Others could go through long preparatory phases, analogous to ongoing lateral spreading deformation at Lesista Wielka (Migoń et al., 2010), followed by brief episodes of significant movement. Finally, some may have been of creeping type throughout their lifetimes, consistent with rather subtle dendrogeomorphological signals (Malik et al., 2016). Thus, their 'extremism' is related to the spatial scale of slope remodelling rather than to the rate of movement.

\subsection{Windthrows}

Geomorphological dimension of wind-induced treethrow events has long remained a neglected subject, despite recurring windthrow calamities (e.g. Kwiatkowski, 1969). A. Jahn went even that far as to say that "gravitational dynamics of soil ends when the slope becomes forested" (Jahn, 1989). Recent work on the effects of the 2007 Kyrill storm on forest stands (Pawlik, 2012, 2013) has redressed the balance and further studies in other parts of the Sudetes (Pawlik et al., 2016, 2017) confirmed the view that significant remodelling of slope morphology and disturbance of slope cover deposits take place in the consequence of massive tree uprooting.

At the scale of an individual uprooted tree the direct effects include the origin of a pit in the place of a former root plate, detachment of bedrock material (soil, cover deposits, but occasionally also jointed solid rock) and its horizontal displacement (Fig. 6). As the degradation of the airlifted root plate proceeds, a mound forms next to the pit, leading eventually to the origin of characteristic paired pitand-mound topography of the forest floor. Dimensions of pits and mounds vary but relatively recent landforms may be up to $1.5 \mathrm{~m}$ deep and high, respectively, whereas their diameters are within the 2-5 $\mathrm{m}$ range. Over time, pits become infilled and mounds flattened and it is estimated that lifetimes of these minor landforms are of the order of 100 years. If bedrock is at shallow depth and roots are strong, bedrock mining occurs and quite large rock fragments, in excess of $1 \mathrm{~m}$, can be brought to daylight (Pawlik et al., 2013).

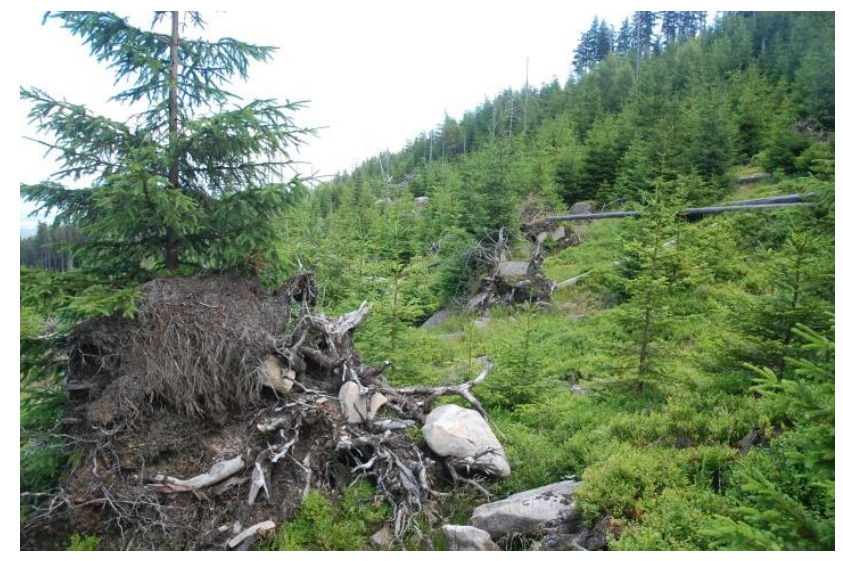

Figure 6 Geomorphic effects of windthrow: origin of pits and initiation of considerable mixing of regolith

Despite relatively short lifetimes, pit-andmound associations are fairly common in the Sudetes, indicating that wind-driven tree uprooting is a frequent phenomenon. The density of pits and mounds may reach 40 pairs per hectare and the 
spatial coverage approaches 5\%. However, the distinctiveness of pits and mounds is also related to the type of tree, its age and the depth of regolith. Thus, widespread tree uprooting took place in the volcanic terrain of the Kamienne Mountains during the Kyrill storm (Pawlik, 2012), but not too many pits originated on steep slopes with rather thin regolith. Nevertheless, mixing of regolith was extensive, stepped microtopography of the slope started to evolve and any older sedimentary structures within cover deposits were destroyed.

In addition to the direct effects, tree uprooting brings about various secondary consequences. Pits and fallen logs affect pathways of overland flow, diverting it from downslope movement, with pits acting as local depositional basins. Mounds in turn are affected by surface flow, soil creep and ground ice development. Surface flow acts selectively, washing away the fines, and gravel armours form at the expense of mounds (Pawlik et al., 2013).

\subsection{Episodes of extreme linear erosion}

In undisturbed mixed or coniferous forest, which are native plant associations in the Sudetes, little erosion is accomplished through either linear or surface flow. However, centuries of forest management, still ongoing except limited areas under strict protection, have resulted in the development of an extensive network of forest roads, logging paths and hiking trails. Their density may be considerable and reaches $10 \mathrm{~km}$ per $1 \mathrm{~km}^{2}$ (Kasprzak, 2006). Their surfaces are occasionally paved but much more often they are not and hence, concentrated flow during heavy rainfall episodes is capable to efficiently erode bare surfaces of communication tracks. Singular rainfall and surface flow events may result in the origin of incisions exceeding $1 \mathrm{~m}$ deep (Fig. 7) (Parzóch and Migoń, 2010), with extreme values of nearly $4 \mathrm{~m}$ recorded in the Karkonosze in September 1994 (Parzóch, 2002) and more than $4 \mathrm{~m}$ during the protracted period of heavy rain in July 1997, in the Śnieżnik Massif (Czerwiński and Żurawek, 1999). Such massive erosion is matched by extensive deposition on local mid-slope flats and at valley confluences, although most of eroded material reaches channels and is included into bedload.

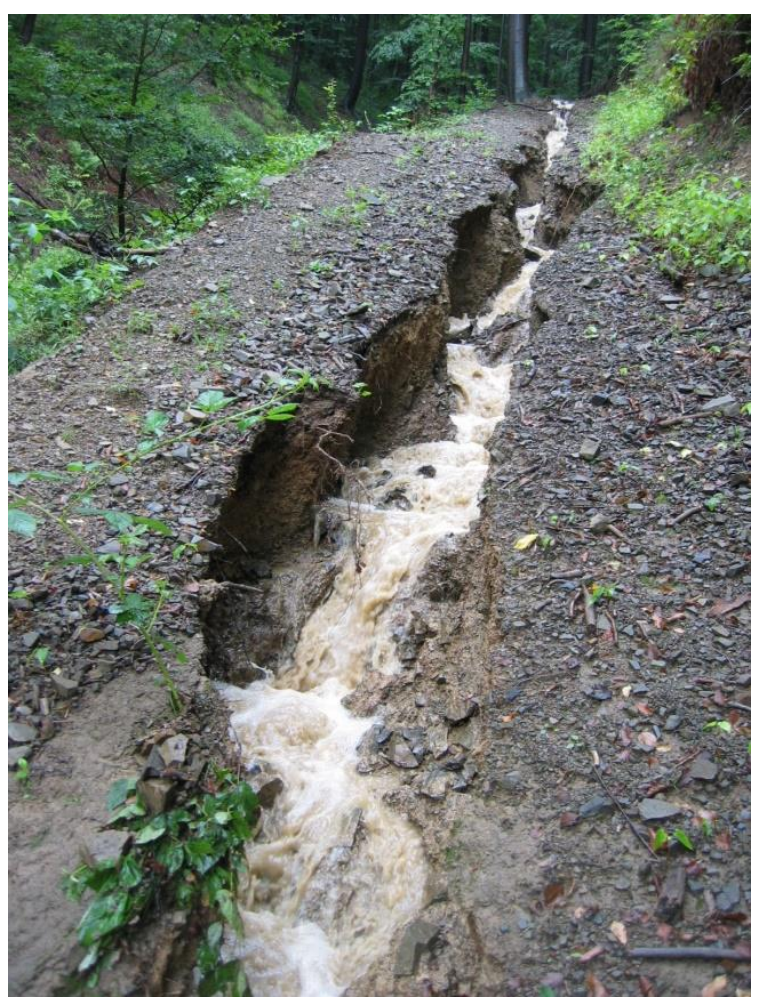

Figure 7 An example of heavy linear erosion due to one rainfall episode (August 2006) within an anthropogenically disturbed ground

In fact, gullies under forest are quite common in certain parts of the Sudetes (Latocha, 2014), especially in the vicinity of old (late medieval - early modern times) centres of mining and ore processing. Their depth reaches $3 \mathrm{~m}$ and the length is of the order of hundreds of metres. It may be speculated that dense networks of gullies have developed progressively, with older roads abandoned after rainfall episodes made them too deep and narrow to be used any longer.

\section{Discussion}

\subsection{Extreme events in space}

Generally, extreme events in the hillslope geomorphological system of the Sudetes exert local rather than regional impact. In historical times, large parts of the Sudetes did not experience any significant geomorphic change consequent to high magnitude atmospheric processes. Even if heavy 
rain or strong wind affects an area of the order of tens of square kilometres, geomorphic effects may still be quite localized. For example, only one debris slide occurred on the slopes of the Czarna valley in the Śnieżnik Massif in 2011, despite the heavy rain affecting the entire drainage basin (Parzóch et al., 2012). Similarly, the episode of severe convective rain over the upper catchment of Bystrzyca Dusznicka produced shallow landslides only along steep valley sides in sedimentary bedrock (Żurawek, 1999), with no comparable processes in the adjacent metamorphic part of the catchment. For most of the forested part of the Sudetes, the state of "no sudden change" seems indeed a norm. Even if processes acting over longer time intervals are considered, the tendency towards spatial clustering can be still observed. The Łomniczka valley in the Karkonosze is notorious for debris flows and more than 25 distinct tracks have been identified until 2006 , with all of them on the western valley side and in the valley head, and none on the eastern valley side (Fig. 3) (Migoń and Parzóch, 2008). This indicates the role of local factors, in addition to the atmospheric triggers. In this example, debris flows were confined to granite bedrock and apparently absent on metamorphic substratum (or so infrequent that old examples have been completely erased). However, in 2009 a small debris slide/flow occurred on the metamorphic rock (although above the timberline). At a larger spatial scale, Hrádek (1984) linked spatial clustering of debris flows in the northern part of Hruby Jeseník (Keprník massif) and their absence in the southern part (Praděd massif) with the presence of well-developed foliation planes, broadly accordant with the slope and acting as sliding surfaces, in the former area.

At a more local scale, geomorphic events considered in this paper may be divided into those whose effects are linear (debris flows, forest road erosion) and those whose effects are distributed over larger surfaces (landslides, windthrow). The results of the former may be impressive, especially if considering duration of formative events, but one needs to realize that the slope section affected is only $1-10 \mathrm{~m}$ wide, rarely more than this. Adjacent surfaces may be left without any signs of surface remodelling. Landslides and windthrows affect much larger areas, measured in hectares (tens of hectares), which is however still very little on the scale of the entire mountain range. Nonetheless, 'hotspots' of landsliding can be identified, e.g. in several parts of the Kamienne Mountains (Migon et al., 2017) where landslides of different types occur next to one another, forming large complexes of 30-50 ha. An analogous spatial clustering of slopes affected by strong wind can be recognized in the Karkonosze Mountains (Pawlik et al., 2016). Considering geomorphic effects of windthrows it should be noted that landforms resultant from tree uprooting are short-lived and their dimensions are much smaller than of those resultant from landslides. However, effects on the regolith structure may be considerable and recent work on mountain soils suggests that poorly horizonated Cambisols, typical for forested slopes, provide pedological record of ongoing disturbance by surface and near-surface processes (Kabała et al., 2013).

\subsection{Extreme geomorphic events in time - triggering mechanisms}

Triggering mechanisms of geomorphic events considered in this paper are exclusively meteorological and related to high precipitation, notwithstanding speculations that seismic factor may have contributed to the 1598 Bardo landslide (Ciężkowski and Koszela, 1988). However, to establish threshold values for debris flows and surface erosion is not easy because of insufficient spatial coverage of rain gauging stations. Available data allow to suggest that rainfall intensities above $20 \mathrm{~mm}^{*} \mathrm{hr}^{-1}$ are necessary to set the debris cover in motion but antecedent moisture is also an important factor as demonstrated by most debris flow events in the Karkonosze (Parzóch and Migon, 2010) and the circumstances leading to the 2011 debris slide in the Śnieżnik Massif (Parzóch et al., 2012).

Recurrence intervals of extreme geomorphic events should be considered at two spatial scales: (a) relevant to the entire Sudetes and (b) in respect to specific localities. Regarding the former, heavy rainfall with reported erosional effects on slopes somewhere in the Sudetes occurs every 3-5 years. 
Debris flow/slide incidents are less frequent and highly irregular. The most recent ones occurred in 2006, 2009 (both in Karkonosze), 2010 (Jizerské hory) and 2011 (Śnieżnik Massif), with no significant events since. These were preceded by 1997 and 1994 events, but there was a much longer quiet interval before (up to 1974). Thus, 1-2 events per decade on average may be hypothesized, although they vary in intensity. In addition, the 2006 and 2009 events occurred above the timberline, so that the regionally applicable recurrence interval for debris flows on forested slopes is longer, approximately once in a decade. Strong winds exerting significant damage in forest stands and hence, altering slope geomorphic systems, occur approximately once every 30-40 years (Pawlik, 2012). The 2007 Kyrill storm was preceded by events of similar magnitude in 1930 and 1966, whereas the most recent, although more localized damage occurred in the Bystrzyckie Mountains and Śnieżnik Massif in 2015.

At the scale of specific localities the recurrence intervals are much longer, although it is important to distinguish between meteorological events and geomorphic events. Heavy rain with intensities capable of triggering debris flows in the Karkonosze occurs at least once per decade, but debris flows in the same locality are triggered with much lower frequency which is mainly due to sediment exhaustion. Again, the headwater part of the Łomniczka valley is a good example. Seven larger debris flows were triggered by heavy rain in September 1994 whereas only one followed the heavy rain episode in July 2009. However, scars and bare granite surfaces left by the 1994 flows are still visible and the source of material was clearly not yet replenished by subsequent weathering.

Any discussion about frequency of hillslope geomorphic events over longer timescales beyond the observation period, in the absence of geochronological data, is at best speculative. The only attempt was that by Pawlik et al. (2016) in respect to tree throw. They proposed that complete soil turnover due to uprooting may have occurred 2-6 times during the Holocene at wind exposed localities. Thus, it is not really possible to establish the representativeness of the last 150 years for the entire Holocene.

\subsection{Implications for the present-day geomorphic systems}

Although the observational basis is still scarce and significant gaps in our understanding of hillslope geomorphological system of the Sudetes remain, it is clear that the forest belt is not a dormant environment, moulded only by low magnitude processes, which has retained most of its preHolocene morphology. Sudden geomorphic events triggered by heavy rain or strong wind do occur, especially on slopes $>20^{\circ}$. In specific circumstances, provided by the combination of rain/wind intensity and suitable local topographic and geological conditions, such events are capable of accomplishing total forest destruction, complete regolith removal, incision down to bedrock and creating significant new landform assemblages over a few to a few tens of hectares. Landslides, even if infrequent, may reshape entire slopes.

The preceding discussion also showed that a combination of factors is necessary to generate an extreme geomorphic event in the forested environment of the Sudetes. Rain or wind are the necessary external triggers, but have to affect slopes which are sufficiently steep and covered by regolith that can be mobilized. Material availability is an important prerequisite, as testified by the fact that recurrence intervals of geomorphic events are longer than those of hydrometeorological events. In addition, human impact becomes a factor and it is proposed that linear erosion on forested slopes, leading to the origin of gullies under forest, would not be possible without surface disturbance and vegetation removal by people.

The challenge for the future is to set these observations in the broader temporal context of the Holocene. There were climatic and environmental fluctuations during the Holocene and it is not known how these may have impacted geomorphic systems. Sediment analysis from the Mały Staw lake in the Karkonosze suggests that an interval of significant erosion occurred around $8.2 \mathrm{ka}$, possibly linked with climate deterioration (Malkiewicz et al., 2016). In the sandstone tableland of the Stołowe Mountains thick sandy covers are widespread on slopes, probably the effects of surface wash (Waroszewski et al., 2015; Duszyński et al., 2016). 
Their presence implies less dense vegetation cover than today as processes of areal sand redistribution do not occur nowadays in forests with dense undergrowth. Scarce geochronological data and proxy soil data suggest mid-Holocene landslide activity in the Kamienne Mountains but it is not known whether they signify birth or reactivation (Kacprzak et al., 2013). Even the status of the Little Ice Age is uncertain and whereas there are indicators that floods may have occurred with greater frequency (Kasprzak and Migon, 2015), the behaviour of slopes remains an enigma.

\section{Conclusions}

Forested hillslopes of medium-altitude Central European mountains built of basement rocks such as the Sudetes should not be equated with the domain of geomorphic stability and periglacial inheritance. Although some places may have preserved most of their periglacial signatures, other show variable and repetitive activity and landform change. The region of Central Europe is exposed to extreme meteorological events and some of them are of sufficiently high magnitude to trigger sudden regolith displacements on steep slopes in the form of debris flows and landslides, linear erosion of cover deposits, or widespread forest calamities with geomorphological implications. The frequency of such events is nevertheless low which makes them difficult to predict in respect to both space and time. Likewise, as a consequence of sparse data base, to establish meaningful threshold values to initiate these processes is not straightforward. The example of the Sudetes shows that the combination of factors is normally necessary for an extreme geomorphic process to occur under forest. Local topographic and geological conditions are vital constraints. The frequency of extreme geomorphic events on the slopes of the Sudetes can only be established for the last 150 years or so. It is not certain whether this period can be considered representative for the Holocene and future research efforts should be focused on the geomorphic history of earlier time intervals of the Holocene.

\section{References}

Aichler J, Pecina V. 1998. Documentation of landslips associated with floodings in 1997 in the Jesenik region. Geologické výzkumy na Moravě a ve Slezsku v roce 1997, 94-96 (in Czech).

Ciężkowski W, Koszela S. 1988. Tremblements de terre locaux dans les Sudetes, SW Pologne, et certaines de leurs consequences. In: Marinos PB, Koukis GC (eds.), The Engineering Geology of Ancient Works, Monuments and Historical Sites. Balkema, Rotterdam, 1285-1289.

Czerwiński J, Żurawek R. 1999. The geomorphological effects of heavy rainfalls and flooding in the Polish Sudetes in July 1997. Studia Geomorphologica Carpatho-Balcanica 33: 27-43.

Duszyński F, Migoń P, Kasprzak M. 2016. Underground erosion and sand removal from a sandstone tableland, Stołowe Mountains, SW Poland. Catena 147: 1-15.

Duszyński F, Jancewicz K, Kasprzak M, Migoń P. 2017. The role of landslides in downslope transport of caprockderived boulders in sedimentary tablelands, Stołowe Mts, SW Poland. Geomorphology 295: 84-101.

Hrádek M. 1984. Appearance of domal morphostructure in some mountains of the Western European Platform and its causes. Sborník prací, Institute of Geography CS AS, Brno 5: 53-60.

Jahn A. 1989. The soil creep on slopes in different altitudinal and ecological zones of Sudetes Mountains. Geografiska Annaler 71A: 161-170.

Jancewicz K, Traczyk A. 2017. Little known manifestations of mass movements in the Węglówka valley in the Bardzkie Mountains (Middle Sudetes). Przyroda Sudetów 20: 289-314 (in Polish).

Kabała C, Bogacz A, Łabaz B, Szopka K, Waroszewski J. 2013. Diversity, dynamics and threats to soils. In: Knapik R, Raj A (eds.), Przyroda Karkonoskiego Parku Narodowego. Karkonoski Park Narodowy, Jelenia Góra, 91-126 (in Polish).

Kacprzak A, Migoń P, Musielok Ł. 2013. Using soils as indicators of past slope instability in forested terrain, Kamienne Mts, SW Poland. Geomorphology 194: 65-75.

Kasprzak M. 2006. Water erosion on roads and tourist trails in the Karkonosze Mountains. Przyroda Sudetów 9: 179-190 (in Polish).

Kasprzak M, Migoń P. 2015. Historical and recent floods in the West Sudetes - geomorphological dimension. Zeitschrift für Geomorphologie NF59, Suppl 3: 73-97. 
Kleber A, Terhorst B. (eds.) 2013. Mid-Latitude Slope Deposits (Cover Beds). Developments in Sedimentology 66, Elsevier, Amsterdam. 302 p.

Kotarba A, Starkel L. 1972. Holocene morphogenetic altitudinal zones in the Carpathians. Studia Geomorphologica Carpatho-Balcanica 6: 21-35.

Kotarba A, Kaszowski L, Krzemień K. 1987. High-mountain denudational system of the Polish Tatra Mountains. Geographical Studies IG i PZ PAN, spec. issue 3, 1106.

Kotarba A, Rączkowska Z, Długosz M, Boltižiar M. 2013. Recent debris flows in the Tatra Mountains. In: Lóczy D (ed.), Geomorphological Impacts of Extreme Weather. Case Studies from Central and Eastern Europe. Springer, Dordrecht, 221-236.

Kowalski A. 2017. Distribution and origin of landslides in the Bóbr gorge in the vicinity of Wlen (West Sudetes). Przegląd Geologiczny 66: 629-641 (in Polish).

Kwiatkowski J. 1969. Climatological origin of forest windthrow areas in the Karkonosze Mts. Czasopismo Geograficzne 40: 365-373 (in Polish).

Latocha A. 2007. Environmental Change in the East Sudetes under Human Impact. Studia Geograficzne 80, Wydawnictwo Uniwersytetu Wrocławskiego: 1216 (in Polish).

Latocha A. 2009. Land use changes and longer-term human-environment interactions in a mountain region (Sudetes Mountains, Poland). Geomorphology 108: $48-57$.

Latocha A. 2014. Geomorphic connectivity within abandoned small catchments (Stołowe Mts, SW Poland). Geomorphology 212: 4-15.

Malik I, Wistuba M, Migoń P, Fajer M. 2016. Activity of slow-moving landslides recorded in eccentric tree rings of Norway spruce trees (Picea abies Karst.) - an example from the Kamienne Mts. (Sudetes Mts., Central Europe). Geochronometria 43: 24-37.

Malkiewicz M, Waroszewski J, Bojko O, Egli M, Kabała C. 2016. Holocene vegetation history and soil development reflected in the lake sediments of the Karkonosze Mountains (Poland). The Holocene 26: 890-905.

Migoń P. 2011. Geomorphic diversity of the Sudetes Effects of global change and structure superimposed. Geographia Polonica 84, Special Issue 2: 93-105.

Migoń P, Parzóch K. 2008. Debris flows in the Sudetes. Przegląd Geograficzny 80: 385-401 (in Polish).

Migoń P, Hrádek M, Parzóch K. 2002, Extreme geomorphic events in the Sudetes Mountains and their long-term impact. Studia Geomorphologica Carpatho-Balcanica 36: 29-49.

Migoń P, Pánek T, Malik I, Hradecký J, Owczarek P, Šilhán K. 2010, Complex landslide terrain in the Kamienne
Mountains, Middle Sudetes, SW Poland. Geomorphology 124: 200-214.

Migoń P, Jancewicz K, Kasprzak M. 2014. The extent of landslide-affected areas in the Kamienne Mountains (Middle Sudetes) - a comparison of geological maps and a LiDAR based digital elevation model. Przegląd Geologiczny 62: 463-471 (in Polish).

Migoń P, Jancewicz K, Różycka M, Duszyński F, Kasprzak M. 2017. Large-scale slope remodelling by landslides - geomorphic diversity and geological controls, Kamienne Mts, Central Europe. Geomorphology 289: 134-151.

Oberc J. 1957. The region of Bardzkie Mountains. Wydawnictwa Geologczne, Warszawa, 284 p. (in Polish).

Pánek T, Smolková V, Šilhán K, Hradecký J. 2013. The May 2010 landslide event in the eastern Czech Republic. In: Lóczy D (ed.), Geomorphological Impacts of Extreme Weather. Case Studies from Central and Eastern Europe. Springer, Dordrecht, 205-219.

Parzóch K. 2002. Erosional processes on deforested slopes in the Karkonosze Mts. Zeszyty Problemowe Postępów Nauk Rolniczych 487: 239-247 (in Polish).

Parzóch K, Migoń P. 2010. Extreme events in the slope system - gravitational mass movements and soil erosion. In: Migoń P (ed.), Wyjątkowe zdarzenia przyrodnicze na Dolnym Śląsku i ich skutki. Rozprawy Naukowe Instytutu Geografii i Rozwoju Regionalnego Uniwersytetu Wrocławskiego 14: 205-239 (in Polish).

Parzóch K, Pawlik Ł, Solarska A, Witek M. 2012. Landslide on the slopes of Mt. Średniak in the Śnieżnik Kłodzki massif in 2011. Przyroda Sudetów 15: 197-208 (in Polish).

Pawlik Ł. 2012. Forest damage in the Sudety Mts. caused by the Kyrill storm (18-19.01.2007) - historic and regional implications. Przegląd Geograficzny 84: 53-75 (in Polish).

Pawlik $Ł$. 2013. The role of trees in the geomorphic system of forested hillslopes - a review. Earth-Science Reviews 126: 250-265.

Pawlik Ł, Migoń P, Owczarek P, Kacprzak A. 2013. Surface processes and interactions with forest vegetation on a steep mudstone slope, Stołowe Mountains, SW Poland. Catena 109: 203-216.

Pawlik Ł, Migoń P, Szymanowski M. 2016. Local- and regional-scale biomorphodynamics due to tree uprooting in semi-natural and managed montane forests of the Sudetes Mountains, Central Europe. Earth Surface Processes and Landforms 41: 12501265.

Pilous V. 1977. Structural debris flows in the Karkonosze Mts. - Part III. Opera Corcontica 14, 7-94 (in Czech). 
Pilous V. 2011. Rainfall-induced debris flows in the upper Směda catchment in the Jizerské hory. Sbornik Severočeského Muzea, Prírodni Vědy 29: 3-40 (in (zech).

Rączkowska Z, Łajczak A, Margielewski W, Święchowicz J. 2012. Recent landform evolution in the Polish Carpathians. In: Lóczy D, Stankoviansky M, Kotarba A (eds.), Recent Landform Evolution. The CarpathoBalkan-Dinaric Region. Springer, Dordrecht, 47-101.

Remisz J. 2012. Variability of the contemporary activity of scree cones in the Sudetes. Czasopismo Geograficzne 83: 93-105 (in Polish).

Remisz J, Bijak Sz. 2012. Dendrochronological record of scree cone activity at Mt. Suchawa and Krucza Skała (Middle Sudetes). Przyroda Sudetów 15: 209-218 (in Polish).

Roštínský P, Šenfeldr M, Maděra P. 2013. Effects of dwarf pine stands on slope deformation processes, as a basis for their management in the Hrubý Jeseník mountains. Journal of Landscape Ecology 6: 63-83.

Różycka M, Migoń P, Michniewicz A. 2017. Topographic Wetness Index and Terrain Ruggedness Index in landslide studies, on examples from the Sudetes, SW Poland. Zeitschrift für Geomorphologie NF 61, Suppl 2: 61-80.
Sobik M. 2005. Climate. In: Fabiszewski J (ed.), Przyroda Dolnego Śląska. PAN, Wrocław, 39-57 (in Polish). Poland.

Sobik M, Błaś M. 2010. Extreme meteorological events. In: Migoń P (ed.), Wyjątkowe zdarzenia przyrodnicze na Dolnym Śląsku i ich skutki. Rozprawy Naukowe Instytutu Geografii i Rozwoju Regionalnego Uniwersytetu Wrocławskiego 14: 35-80 (in Polish).

Synowiec G. 2005. Landslide forms and processes in the Kamienne Mountains. Institute of Geography and Regional Development, University of Wrocław, PhD Thesis (in Polish).

Treml V, Banaš J. 2003. Alpine timberline in the High Sudetes. Acta Universitatis Carolinae, Geographica 15: 83-99.

Valde-Nowak P. (ed.) 1999. The beginnings of the settlement in the Sudetes. Instytut Archeologii $\mathrm{i}$ Etnologii PAN, Kraków, 238 p. (in Polish).

Waroszewski J, Malkiewicz M, Mazurek R, Labaz B, Jezierski P, Kabała C. 2015. Lithological discontinuities in Podzols developed from sandstone cover beds in the Stolowe Mountains (Poland). Catena 126: 11-19.

Żurawek R. 1999. Flood-driven geomorphic changes in the river valleys of the Kłodzko Sudetes due to July 1997 and July 1998 events. Problemy Zagospodarowania Ziem Górskich 45: 43-61 (in Polish). 